\title{
5 \\ Integriranje dohodkov v kmečki ekonomiji v poznem srednjem veku
}

\author{
Matjaž Bizjak \\ Zgodovinski inštitut Milka Kosa \\ ZRC SAZU \\ Novi trg 2, Ljubljana \\ matjaz.bizjak@zrc-sazu.si
}

\section{Uvod}

Kmečka trgovina in široka paleta drugih neagrarnih dejavnosti slovenskega kmečkega prebivalstva, ki so $\mathrm{v}$ vsej svoji pestrosti dokumentirane $\mathrm{v}$ zgodnjem novem veku, se niso nenadoma pojavile šele takrat. Zametke teh pojavov gre iskati $\mathrm{v}$ srednjem veku. Za pravilno razumevanje preučevanih pojavov je nujno poznavanje vzrokov, ki so privedli do njih, in razmer, v katerih so se izoblikovali. Med njimi lahko vsekakor izpostavimo uvedbo denarnega gospodarstva, ki je bilo - vzporedno z naturalnim - pri nas v veljavi vsaj od 12. stoletja dalje, demografske in klimatske spremembe, zaostrovanje makroekonomskih razmer v poznem srednjem veku, predvsem pa vlogo zemljiškega gospostva kot iniciatorja presežne kmetijske proizvodnje, podeželske obrtne dejavnosti in kmečke trgovine. $\mathrm{Na}$ osnovi dosedanjih raziskav in poznavanja konkretnih zgodovinskih virov je mogoče postaviti hipotezo, da ima večina neagrarnih dejavnosti, dokumentiranih v zgodnjem novem veku, svoj izvor oz. neke predhodne faze $\mathrm{v}$ srednjem veku. Namen tega prispevka je preveriti in v končni fazi potrditi ali ovreči omenjeno hipotezo v splošnem kot tudi v vseh posameznih segmentih.

Pomemben vidik tega raziskovalnega problema je vpliv zemljiškega gospostva na kmetijsko proizvodnjo. V obravnavanem prostoru si je za obdobje srednjega veka, vsaj nekje od 12. stoletja dalje, pravzaprav težko predstavljati kmetijsko dejavnost zunaj okvirov zemljiškega gospostva; če pa že, je le-ta tvorila zelo majhen delež celotnega sektorja. Kmečko prebival- 
stvo se je v veliki večini uvrščalo v diferenciran podložniški sloj ljudi, podrejenih neki pravni ali fizični osebi iz višjih družbenih slojev. Te pravne ali fizične osebe (plemiči od najnižje rangiranih do vladarjev, cerkvene institucije, kot so škofije, samostani, župnije pa tudi posamezne cerkvene stavbe in bratovščine, vezane na določen oltar v neki cerkvi) oz. njihovo oblast nad kmetijskimi obrati, vključno $\mathrm{z}$ na njih nastanjenim prebivalstvom, lahko enačimo s pojmom zemljiško gospostvo. Gledano z ekonomskega vidika lahko ta gospostva obravnavamo kot širše organizacijske enote ali obrate kmetijske proizvodnje, ki so $\mathrm{z}$ zahtevami do neposrednih proizvajalcev - te pa so temeljile na spreminjajočih se potrebah višjih družbenih slojev - pomembno vplivale na kmetijsko proizvodnjo in jo $\mathrm{v}$ bistvu do neke mere tudi usmerjale. $V$ grobem so se posledice teh zahtev kazale $v$ povečevanju obsega kmetijske proizvodnje, njeni specializaciji za potrebe gospostva, gospoda in tudi trga ter vstopu podložnikov na trg kot posledici vedno močnejših tendenc po denarnih dajatvah. A kazale so se tudi v razvijanju lastne infrastrukture, kar je usmerjalo kmečko prebivalstvo v neagrarne dejavnosti, spet sprva za lastne potrebe gospostva in pozneje tudi za potrebe trga. Tipičen primer tega pojava je vznik naselbin s poudarjeno neagrarno dejavnostjo $\mathrm{v}$ neposredni bližini gradov kot centrov zemljiških gospostev, ki so se lahko - ne pa nujno - sčasoma razvile v urbana naselja.

Neagrarne in druge dejavnosti, s katerimi so kmetje presegali samooskrbno kmetovanje in katerih korenine gre iskati $\mathrm{v}$ srednjem veku, je mogoče najti v različnih sferah gospodarstva. Tako je med dejavnostmi primarnega sektorja zaslediti povečano intenzivnost koriščenja gozdnih površin in krčenje novih obdelovalnih površin ter tudi primere specializacije, zlasti živinorejo in vinogradništvo. V sklopu sekundarnega sektorja je mogoče navesti oblike predelave pridelkov in naravnih virov (vinarstvo, sirarstvo, apnarstvo in oglarstvo) ter različne obrti, med dejavnosti terciarnega sektorja pa vsaj prodajo kmetijskih pridelkov na trgu, tovorništvo in prevozništvo na kratke in srednje razdalje in kot nekakšno krono vsega povedanega, zadnji stadij v razvoju, kmečko trgovino.

\section{Primarni sektor}

\subsection{Koriščenje gozdnih površin}

Gozd je bil od vsega začetka kmetov najpriročnejši vir raznovrstnih surovin. V njem se je oskrboval z gradbenim in s kurilnim lesom, raznimi plodovi za prehrano in krmo, $\mathrm{z}$ listjem in s praprotjo za steljo kot tudi lovil manjšo divjad. Regulacija izkoriščanja gozdnih virov je že v srednjem veku 
dosegla precej visoko raven; pojavi se z vznikom oz. uveljavitvijo zemljiških gospostev. Na ozemlju današnje Slovenije se je ta proces odvijal predvsem od konca 10. (v obdobju po madžarskih vpadih na ozemlje cesarstva) pa do konca 11. stoletja (Vilfan 1980, 106-7). Pravni temelj regulativi sta nedvomno predstavljala pojmovanje in praksa, po katerih je vse do tedaj neprilaščeno ozemlje pripadlo vladarju. S tem je dejansko vladar avtomatično pridobil obsežna neposeljena, skoraj izključno z gozdom pokrita območja (Vilfan 1980, 108). Gospodarski pomen omejevanja izkoriščanja gozdov je bil zagotavljanje naravnih virov zemljiškim gospostvom, ki so jih v tem času intenzivno ustanavljali prejemniki obsežnih površin kronske zemlje (Vilfan 1980, 133-41; Štih 2005, 37-53; Štih 2006, 24-30). V tej prvi fazi se je omejevanje izkoriščanja $\mathrm{v}$ pretežni meri skoncentriralo na lov divjadi, kar je dokumentirano $\mathrm{v}$ številnih podelitvah lovske pravice (=Wildbann), s katerimi je bila le-ta izključno pridržana prejemnikom, tj. zemljiškim gospodom (Dasler 2001, 13 sl). Vsekakor je bilo v pristojnosti zemljiških gospostev tudi reguliranje ostalih vrst koriščenja gozda (sečnja gradbenega in kurilnega lesa, šibja, kolov in vejevja, gozdna paša in krčenje gozdnih površin $s$ požigom za kmetijsko obdelavo), ki pa je bilo $\mathrm{v}$ skladu s potrebami in z gospodarskimi koristmi - seveda pod nadzorom - prepuščeno podložnikom gospostva (Blaznik 1970, 151-2). Nenazadnje v ta sklop sodi pomemben proces trajne preobrazbe določenega deleža gozdnih površin $\mathrm{v}$ obdelovalne, ki ga je povzročila kolonizacija (Kos 1970, 69-70; Zwitter 2013, 85-98).

Povedano razmeroma dobro opisuje stanje na območju zemljiških gospostev, ki so nastala na pretežno neposeljenih, kolonizacijskih ozemljih - izrazit primer v slovenskem prostoru je Škofja Loka (Blaznik 1973, 11-6; Štih, 2005, 44-5). Nekoliko manj takšna razlaga ustreza gospostvom, ki so nastala s podelitvami pretežno že poseljenih območij, kjer so bile vsakršne podelitve v veliki meri odvisne od praktične sposobnosti uveljavljanja podeljenih pravic nasproti obstoječim pravnim subjektom. Na ozemlju blejskega briksenskega gospostva je, denimo, v drugi polovici 11. stoletja dokumentiran primer posedovanja lovske pravice (bannum ferrarum) $\mathrm{s}$ strani lokalnega nižjega plemstva $\mathrm{v}$ mejah ozemlja, nad katerim je škofija že nekaj desetletij pred tem prejela izključno lovsko pravico (Redlich 1886, 108).

V naslednjih stoletjih je prišlo do diferenciacije med eksplicitno lovsko in splošnejšo gozdno pravico (ius forestum, forstrecht), ki je pokrivala vsa druga področja izrabe gozdnih virov razen lova (Blaznik 1980, 250). Od 13. stoletja dalje obe postaneta predmet pravnega prometa (fevdne podelitve, 
prodaje, zastave in zakupi) med imetniki zemljiških gospostev, ki so bili v glavnem omejeni na cerkveno in posvetno plemstvo (Otorepec 1995). ${ }^{\mathrm{I}}$ Proti koncu srednjega veka, $\mathrm{v}$ manjši meri in le na najnižjem nivoju so se $\mathrm{v}$ ta proces vključevali tudi nekateri meščani.

Tekom srednjega veka je nadzor nad izkoriščanjem gozda večinoma ohranjalo zemljiško gospostvo preko svojega upravnega aparata (v loškem gospostvu ima na primer vsak zemljiški urad svojega gozdarja - vorstarius). V obliki podložniške tlake - sečnja, plavljenje in odvoz gradbenega in kurilnega lesa, žganje apna, sekanje šibja in kolov (Blaznik 1963, 21921) - ali pa dajatev - oddaja klanih desk oz. skodel, kolov za vinograde, šibja za obroče sodov (Bizjak 2006b, 60, 77; Bizjak 2007, 88, 122; Bizjak in Žižek 2010, 36-7; Bizjak 2013, 88) ${ }^{2}$ - so bila običajno regulirana dela, ki so se nanašala na črpanje gozdnih surovin za potrebe gospostva. Poleg tega so gospostva svojim podložnikom dovoljevala koriščenje omenjenih surovin za lastne potrebe, praviloma posameznim soseskam na določenem ozemlju. Slednje je razvidno iz listin, ki regulirajo spore med podložniki različnih gospostev, ki so nastali na mejnih ozemljih oz. tam, kjer je po principu fevdalnega partikularizma prišlo do nastanka oz. odcepljanja novih gospostev iz okvira prvotnih. ${ }^{3}$

Vsekakor pa se podložniki niso vedno držali omejitev, ki so pogojevale zgolj njihovo lastno uporabo v okviru kmečkega gospodarstva. V sporih med radovljiškimi podložniki in blejskim oskrbnikom s konca 15. stoletja je omenjeno, da kmetje plavijo iz gozdov več lesa, kot ga sami potrebujejo (Kaspret 1889, 90). Že v urbarjih s konca 15. stoletja najdemo ponekod urbarialno oddajo različnih lesnih polizdelkov (žagane in klane deske, skodle, hlode), včasih kot nazivno dajatev, včasih pa kot nadomestilo oz. protivrednost za neko drugo obveznost (Kos 1954, 252). Oboje kaže na presežno izkoriščanje lesa, ki se je v končni fazi znašel tudi na trgu. ${ }^{4}$ Že od konca 14. stoletja dalje obračuni škofjeloškega gospostva izkazujejo znatne izdatke za gradbeni les, ki je nedvomno izviral z ozemlja gospostva (Bizjak 2013, 88). Iz podrobnejših virov iz devetdesetih let 15 . stoletja je razvidno, da so za ta

Številni primeri so v obliki regestov zbrani v Otorepec (1995).

K temu še DAK, HS 122, fol. 119. Prim. tudi Bizjak (2013, 88).

Tipičen primer je več kot stoletje trajajoč spor med gospostvom Škofja Loka in mestom Kranj, ki je nastal zaradi konfliktov v zvezi z izkoriščanjem obmejnega gozda v Besnici; obširno o tem Žontar (1939, 79-88). Razen tega še nekaj izbranih primerov: ARS, AS 1063, 1402-VII-29; AS 1063, 1437-VI-22; AS 1063, 1459-VIII-4. 
les plačevali določenim podložnikom iz posameznih uradov gospostva (na primer koroški in brodski). ${ }^{5}$ Takšen notranji odkup se gotovo ni nanašal na surovino, ki je že tako pripadala gospostvu, pač pa na delo podložnikov, ki so les posekali, predelali v polizdelke (deske, skodle ...), ga dostavili na želeno lokacijo in si s tem pridobili dodaten zaslužek. Zadevni seznam iz leta 1491 navaja 20 podložnikov, ki so za lesene polizdelke skupaj prejeli 46 mark in pol (zneski za posamezne podložnike so se gibali med pol in šestimi markami), kar je, za primerjavo, predstavljalo vrednost 23.000 strešnih skodel. ${ }^{6}$

Vseskozi je bilo prisotno tudi nabiranje različnih plodov v gozdu, vendar je v srednjem veku le redko dosegalo pomen gospodarske dejavnosti, ki bi imela komercialni potencial ali bi bila vsaj zanimiva za zemljiško gospostvo. Takšno izjemo predstavlja na primer kostanj, ki so ga kot cenzualno dajatev oddajali nekateri podložniki dolenjskih gospostev Kostanjevica in Štatenberk ter števerjanski podložniki goriškega gospostva (Bizjak 2016, 85-6, 120; Pavlin 2006, 141-4). Dejstvo, da je bil kostanj predmet urbarialne oddaje, kaže na to, da je nabiranje teh plodov že zelo zgodaj doseglo občuten obseg. Nedvomno so del te bere podložniki prodali tudi na trgu. Podobno je bilo verjetno tudi $\mathrm{z}$ nabiranjem žira in želoda za prašičjo krmo oz. pašo prašičev $\mathrm{v}$ gozdovih, za kar so podložniki gospostvu plačevali določeno odškodnino $\mathrm{v}$ obliki dajatve, imenovane žirnina (aßrecht). ${ }^{7} \mathrm{~V}$ vaseh radovljiškega gospostva $\mathrm{v}$ okolici peračiškega gozda je $\mathrm{v}$ letih, ko je obrodil žir, vsak podložnik, ki je v gozdu pasel prašiče, oddajal gospostvu po eno svinjsko pleče. Tudi splošna dajatev za uporabo gozda (vorstrecht) je bila (verjetno v teku časa) prilagojena svinjereji; poravnavali so jo s pečenicami. ${ }^{8}$ Težko bi razumeli zavestno odločitev plačevanja takšne odškodnine s strani podložnikov, če ne bi mogli pričakovati povrnitve, denimo, $\mathrm{s}$ prodajo mesa, niti ne bi bila takšna dajatev smiselna s strani gospostva, če bi bila svinjereja $\mathrm{v}$ zadostni meri regulirana $\mathrm{z}$ oddajo prašičev oz. svinjskega mesa. Verjetneje je pobiranje žirnine odraz povečanega obsega podložniške svinjereje, ki je bila vsaj deloma tudi tržno usmerjena.

Pravice do lova so bili kmetje deležni le v zelo omejenem obsegu. V najboljšem primeru jim je bilo dovoljeno loviti malo divjad, le izjemoma tudi kaj večjega. Zemljiška gospostva so pravico do lova običajno podelje-

5 Register izdatkov 1491, AEM, Heckenstaller's Frisingensia 164, fol. 5.

6 Za ceno glej Bizjak 2003, 105-6.

$7 \quad$ Posamezni primeri v škofjeloških urbarjih (Blaznik 1963, 145, 191, 202, 365).

8 Urbar Radovljica 1498, AS 174, šk. 246, p. 102. 
vala samo določenim skupinam podložnikov, ki so jim praviloma nalagala tudi urbarialne dajatve od te dejavnosti. Soseska v Selu v Vipavski dolini je bila, denimo, dolžna goriškemu gospostvu oddajati jerebice (Pavlin 2006, $68,171)$, podobno posamezne kmetije v Čiginju in Volčah na Tolminskem jerebice in kljunače (Kos 1948, 64-5), škofjeloški urbar iz leta 1318 pa navaja celo vrsto vasi v Selški in Poljanski dolini, ki so oddajale ujede - sokole in jastrebe (Blaznik 1963, 213). Blejske podložnike v Gorjah, Rečici, Žirovnici in Dvorski vasi je bremenila dajatev kunjih kož (Bizjak 2006b, 188, 1969). Posebno pravico do lova na gamse so uživali bohinjski podložniki radovljiškega gospostva v Studorju, domnevno kot odškodnino za straženje deželne meje proti Beneški republiki (Kaspret 1889, 95). Kmetom je bil dovoljen tudi lov na zveri, ki so jim povzročale škodo. Znan je primer s konca 15. stoletja, ko so blejski podložniki uplenili štiri medvede, ki so dalj časa pustošili njihove črede. Ko je oskrbnik od njih terjal določen delež izplena za grajsko kuhinjo, se je izkazalo, da so kmetje celoten ulov že prodali v Radovljico, kar prej kot ne kaže na neko utečeno prakso zalaganja lokalnega trga z divjačino (Kaspret 1889, 83).

Nekaj podobnega je veljalo za ribolov. Tudi ribolovna pravica je prvotno načeloma pripadala gospostvu; tako jo je, denimo, freisinška škofija na škofjeloškem ozemlju pridobila $\mathrm{z}$ darovnicami $\mathrm{v}$ 10. stoletju, vendar so škofje v poznem srednjem veku posamezne revirje podeljevali svojim uradnikom oz. lokalnemu plemstvu. Ob koncu 15. stoletja je bil le še ribolov v Sori od sotočja do meje gospostva pridržan škofu, Poljanska Sora in nekateri potoki v Selški dolini so pripadali oskrbniku gospostva, Selška Sora pa gospodarskemu upravniku, kaščarju (Bizjak 2013, 87). V nekaterih primerih pa so pravico do ribolova prejeli tudi podložniki. Takšna je bila situacija na ozemlju radovljiškega gospostva $\mathrm{v}$ Bohinju. Tamkajšnji kmetje so lovili ribe v Bohinjskem jezeru, v Savi Bohinjki do Bohinjske Bele ter v potokih Velika in Mala Suha ter v Radovni. Ta pravica je bila povezana $\mathrm{z}$ urbarialno oddajo rib, nedvomno pa podložniki pri tej dejavnosti niso zapostavljali lastnih koristi, na kar je mogoče sklepati iz ogorčenega boja, razvidnega iz pritožb, ki jih je povzročilo kratenje teh pravic s strani oskrbnika blejskega gospostva (Kaspret 1889, 91-5). Podložniško ribolovno pravico najdemo še v goriškem gospostvu, in sicer v Podgori pri Gorici, Orehovljah, Vogrskem, Čepovanu in Prvačini (Kos 1954, 155, 158, 161, 165, 188) in verjetno še kje. Nenazadnje je nanjo mogoče sklepati iz praktično vsakotedenskih izdatkov za nakup rib v registru gornjegrajskega gospostva s konca 15. oz. z začetka 16. stoletja (Bizjak 2013, 87). 


\subsection{Specializacija kmetijske proizvodnje}

V srednjeveških virih je na nekaterih območjih opaziti specializacijo kmetijske proizvodnje, ki je karakteristična za določene kmetijske panoge (živinoreja, vinogradništvo). Specializacija kmetijske proizvodnje favorizira pridelavo določenega proizvoda na račun ostalih in s tem prisili kmeta $\mathrm{v}$ menjavo oz. prodajo presežkov. Pridelava na takšnih obratih je zaradi učinka specializacije običajno učinkovitejša, kar prinaša večji donos zemljiškemu gospostvu, v končni fazi pa dotičnega podložnika postavlja v boljši ekonomski položaj.

Specializirana živinoreja (švajge). V tradicionalnem kmetijstvu je imela živinoreja na območjih, primernih za poljedelstvo, specifično vlogo. Domala vse kmetije so gojile delovno (vprežno) živino - na pretežnem delu slovenskega ozemlja predvsem govedo, $v$ manjši meri tudi konje in osle (Novak 1970, 367-8) - in male živali, na primer perutnino, ki so služile prehrani. Medtem ko so kokoši in jajca bolj ali manj redna postavka podložniške oddaje, ostale živalske produkte oz. živino srečujemo le na območjih, specializiranih za živinorejo, tj. predvsem $\mathrm{v}$ hribovitih predelih alpskega in predalpskega sveta ter na Krasu. Poleg živinorejskih dvorov (curtes stabulariae), ki so jih vzdrževala gospostva v lastni režiji oz. v okviru pridvornega gospodarstva, so med specializirane živinorejske obrate sodile švajge oz. sirnice. Švajga je pravni termin za gospodarsko enoto, pogojno rečeno kmetijo, kjer so gojili molzno živino (v slovenskem prostoru pretežno ovce, ponekod tudi govedo) in pridelovali sir. V primerjavi z običajnimi kmetijami, hubami, so zemljiški gospodje v upravo švajg posegali nekoliko intenzivneje. Običajno so jih vzdrževali v okviru gospostva $\mathrm{v}$ stalnem številu, ki je ohranjalo stabilno proizvodnjo sira, in v primeru zapletov po potrebi status švajge podeljevali primernejšim kmetijam.' Skrbeli so za optimalen stalež goveda ali drobnice, v škofjeloškem gospostvu denimo okoli 25 ovac (Blaznik 1963, 122), čemur je bila običajno namenjena spomladanska (ob svetem Juriju) dajatev ovce $\mathrm{z}$ jagnjetom, ovis cum agno (Blaznik 1963, 122; Bizjak 20o6b, 76; Bizjak 2006a, 40). Sir je imel pomembno mesto $\mathrm{v}$ srednjeveški prehrani, predstavljal je glavni vir maščob. Zato ne preseneča, da je bila proizvodnja na ozemlju gospostev $\mathrm{z}$ večjim živinorejskim potencialom tudi komercialno usmerjena. Med vodilne proizvajalce sira sta se v 14 . in 15 . stoletju uvrščali gornjegrajsko

9 Tak primer zasledimo v škofjeloškem obračunu iz let 1400-1401, ko sta propadli dve švajgi v Žireh in je uprava gospostva njuno dejavnost prenesla na dve drugi kmetiji (Bizjak 2006a, 40). Prim. tudi Gestrin 1952-53, 482-3. 
in škofjeloško gospostvo s povprečno letno proizvodnjo okoli 12.000 sirov (Blaznik 1963, 122; Novak 1970, 374). Nekoliko manjša je bila proizvodnja na tradicionalno sirarskem območju lociranega tolminskega gospostva, in sicer okoli 5.000 sirov letno. ${ }^{10}$ Škofjeloški obračuni s konca 14. stoletja izkazujejo razvito prodajno mrežo; med kupci sira se omenjajo stiški opat, oskrbnik blejskega gospostva Kraig in okoliško plemstvo. Preostalo količino sira je ob koncu obračunskega leta odkupil škofjeloški kaščar in ga dalje prodajal v lastni režiji (Bizjak 2005, 2-3, 11, 17, 19; Bizjak 2006a, 30, 41). Omeniti velja še vitanjsko gospostvo krške škofije, kjer so švajge v hribovitem predelu (swaygen an dem perg) z letno proizvodnjo 2.700 hlebcev zalagale upravni sedež škofije v Straßburgu na Koroškem. ${ }^{\text {"I }}$

Vinogradništvo in pivovarstvo. Vinogradništvo je ena od tistih kmetijskih panog, v katerih je zelo zgodaj prišlo do specializacije. Obseg proizvodnje vina $\mathrm{v}$ srednjem veku nikakor ni bil majhen, saj je vino v okviru proizvodnje oz. donosa zemljiških gospostev predstavljalo drugi najpomembnejši artikel, takoj za žitom. Vinogradništvo je bilo razvito v vseh okoljih, ki so tudi danes tradicionalno vinorodna - ohranjeni podatki za srednjeveško obdobje se nanašajo na posamezne predele vseh treh slovenskih vinorodnih regij: Goriška brda, Vipavsko dolino in Kras v primorski regiji (goriška gospostva), dolenjski (gospostva Mokronog, Klevevž, Štatenberk in Kostanjevica) in bizeljski vinorodni okoliš (Bizeljsko) v posavski regiji ter Vitanje in gospostva $\mathrm{v}$ zgornjem Posotelju, ki spadajo v štajerski okoliš podravske vinorodne regije. Med vrstami vin, ki so poznane iz 15., nekatere pa že iz 14. stoletja, ${ }^{12}$ se v goriških obračunih omenjata teran in rebula (Kos 1954, 123-9), v freisinških rebula in muškat (Bizjak 2009, 144), v celjski poleg rebule tudi malvazija in pinela (Bizjak in Žižek 2010, 4-5, 60-1, 68-9, 88-9, 126-7). Predvsem rebula je predstavljala nadvse pomembno tržno blago, ki, denimo, ni bilo nepoznano na Bavarskem in celo Pomorjanskem. ${ }^{13}$ Vinogradništvo je bilo v srednjem veku razširjeno tudi na za to panogo manj ugodnih območjih, denimo na Gorenjskem.

10 Kos 1948, 36. Tolminski urbar sir sicer meri v funtih, ki pa so cenovno (in posledično vsaj okvirno tudi količinsko) primerljivi s kosi/hlebčki, ki jih navaja škofjeloški urbar; Tolmin 2 pfeniga za funt, Škofja Loka 2 do 4 pfenige za hleb (Blaznik 1963, 107, 153, 197, 271; Zahn 1871, 125, 128). Za Gornji Grad Gestrin (1952-53, 482) navaja težo za hleb sira med 1,5 in 3 funti ter ceno 3 pfenige.

11 DAK, HS 122, fol. 124'-126; HS 106, fol. 113.

12 Dokumentirano rebula, vipavec in ljutomerčan leta 1377 (Paravicini 1989, 293; 1995, 129).

13 Ob koncu 14. in v začetku 15. stoletja na primer pogosto srečujemo rebulo na ozemlju nemškega viteškega reda ob Baltiku (Erich 1896, 10, 55-6, 103, 235, 286, 314, 368, 
Medtem ko imamo za blejsko gospostvo zadnje podatke o gojenju vinske trte iz sredine 13. stoletja (Bizjak 2006b, 188), pa se je na škofjeloškem ozemlju ohranilo do začetka 16. Obračuni s konca 14. stoletja beležijo še redno urbarialno oddajo vina, v prvi polovici 15. pa je ta dejavnost, najverjetneje zato, ker na teh legah pridelano vino ni dosegalo zadovoljive kakovosti, za gospostvo postala nezanimiva in so jo začeli postopno opuščati (Blaznik 1963, 121; Bizjak 2005, 6, 12, 22).

Skoraj povsod, kjer srednjeveški viri omenjajo vinogradništvo, naletimo na specializirane kmetijske obrate, ki so se ukvarjali s to dejavnostjo. Že zgodaj so zemljiška gospostva razvila posebno kategorijo t. i. viničarske hube, podložniškega kmetijskega obrata, ki se je v pretežni meri, če že ne izključno, ukvarjal z gojenjem vinske trte in s proizvodnjo vina. Takšne viničarje najdemo na primer na ozemlju freisinškega loškega gospostva - v Stražišču in okolici (Blaznik 1963, 121, 131, 181; Blaznik 1973, 69), freisinškega klevevškega gospostva - v Beli cerkvi (Blaznik 1963, 214, 175; Blaznik 1958, 76-7) in vipavskega gospostva - v Vrabčah in Planini (Kos 1954, 254, 256). Škofjeloški primer kaže izrazito specializacijo; poglavitna zadolžitev tamkajšnjih viničarjev je bila obdelovanje dominikalnih vinogradov, medtem ko je bila sama huba bolj kot ne namenjena lastni oskrbi in podvržena le minimalnim dajatvam (Blaznik 1963, 131, 181, 220-1). Specializirana proizvodnja vina je bila lahko organizirana tudi v okviru urbarialnih hub. Milko Kos navaja, da so posamezne kmetije v okolici Tomaja in na Vipavskem oddajale izključno vino (Kos 1954, 79).

Tudi pivovarstvo je moralo biti v srednjem veku precej razširjeno. Podložniško oddajo hmelja in piva zasledimo predvsem v zgodnejših urbarjih; v Škofji Loki v letih 1160 in 1291 (Blaznik 1963, 128) ter na Bledu v letih 1253 in 1306-1309 (Bizjak 2006b, 185-8, 191, 192), v nekoliko mlajših pa le še denarno nadomestilo za pivo, na primer v Tolminu leta 1377 (Kos 1948, 56, 58). Plemstvo v poznem srednjem veku očitno ni več kazalo tako močnega interesa za doma varjeno pivo, kar pa ne pomeni nujno, da je ta dejavnost na podeželju zamrla. Podložniki krške škofije iz Metniza na Koroškem so, denimo, v 15. stoletju prodajali pivo na trgu v bližnjem Gradesu, zahodno od Brež (Wiessner 1951, 165).

Poleg teh najbolj razširjenih specializiranih kmetijskih panog je bila običajna praksa, vsaj v bolje organiziranih zemljiških gospostvih, ustanavljanja manjšega števila specializiranih hub z nalogo opravljanja različnih 
dejavnosti v interesu zemljiškega gospoda. Škofjeloška urbarja iz let 1291 in $1318 \mathrm{v}$ tem kontekstu navajata kovaške, tesarske in pekovske hube, ki sodijo v sklop kmečkih obrtnih dejavnosti, pa tudi lovske in ribiške hube, ki jih gre obravnavati v sklopu kmetijske specializacije. Podložniki na teh hubah so oskrbovali grajsko kuhinjo z mesom oz. ribami, medtem ko so obdelovali zemljo zgolj za lastno preživljanje. ${ }^{14}$

\section{Sekundarni sektor}

\subsection{Predelava pridelkov in naravnih virov}

Opredeljevanje neagrarnih kmečkih dejavnosti sekundarnega sektorja je do neke mere oteženo, saj se predelava določenih kmetijskih pridelkov v veliki meri navezuje na specializirane panoge poljedelske ali živinorejske proizvodnje, na primer sirarstvo na živinorejo in vinarstvo na vinogradništvo (obravnavano v ustreznih gornjih razdelkih). Podobno se predelava nekaterih drugih naravnih dobrin na eni strani navezuje na intenzivno izkoriščanje gozda (oglarstvo, apnarstvo in izdelava lesnih polizdelkov), na drugi strani pa lahko sodi v okvir obrtnih dejavnosti in je deloma obravnavana $\mathrm{v}$ omenjenem sklopu.

Medtem ko o oglarstvu v srednjeveških virih nimamo prav veliko podatkov - pojavljati se začnejo nekoliko pozneje v kontekstu fužinarskih industrijskih obratov -, smo nekoliko bolje obveščeni o apnarstvu. Apno je $\mathrm{v}$ srednjem veku predstavljalo nepogrešljiv material pri gradnji kamnitih stavb, ki so se - razen v okoljih, kjer je primanjkovalo lesa - poleg sakralnih objektov večinoma omejevale na gradove, stolpe, obzidja in druge utrjene, obrambi namenjene objekte. Zato ne preseneča, da so bila zemljiška gospostva eden glavnih porabnikov in obenem tudi pobudnikov proizvodnje apna, ki je bila običajno organizirana na ozemlju, z naravnimi viri in delovno silo gospostva. Podrobnejšo organizacijo apnjekuhe v 14. in 15. stoletju je mogoče opisati na podlagi dobro ohranjenega gradiva za škofjeloško gospostvo. Opisi, ki so se ohranili v gospoščinskih obračunih (Bizjak 2009, 128-9) in urbarjih (Blaznik 1963, 219, 351) kažejo, da je vsaj do neke mere v osnovi šlo za tlačansko obveznost, ki so jo opravljali podložniki posameznih uradov. Celoten delovni proces je v virih natančno razčlenjen, pri čemer posamezna opravila bremenijo podložnike različnih urbarialnih uradov (delo v kamnolomu, sečnja lesa, transport kamenja, kurilnega lesa,

14 Blaznik 1963, 167, 213; posamezni primeri ribiških hub v Blaznik 1963, 130; Bizjak 2006, 188, 196, 199; posamezni primeri lovskih hub v Blaznik 1963, 131; Kos 1954, 55. 
apna, nadziranje in oskrbovanje apnenice). Že sredi 15. stoletja je moralo gospostvo določena opravila $v$ procesu apnjekuhe (predvsem delo mojstrov, pa tudi nekatera fizična dela: transport, kuhanje apna) plačevati. Očitno je obseg del zaradi naraščajočih potreb po apnu prerasel okvire, ki jih je bilo mogoče kriti s tlaškimi obveznostmi, in določenim podložnikom omogočal dodaten zaslužek (Bizjak 1997, 41-2).

\subsection{Obrtna dejavnost}

Izdelovanje vsakdanjih potrebščin (orodja, posode, oblačil ...) za lastno uporabo človeka spremlja od najzgodnejših časov. Čeprav je do poznega srednjega veka na obravnavanem ozemlju že v veliki meri prevladala osnovna diferenciacija gospodarskih dejavnosti (kmetijstvo, obrt, trgovina), je povsem razumljivo, da so podložniške kmetije v okviru zemljiških gospostev še ohranjale določeno stopnjo samooskrbe tudi $v$ tem pogledu. Izdelovanje predmetov za lastno rabo je bila tista osnova, iz katere se je lahko razvila obrtna dejavnost, ki je bila sprva morda usmerjena v blagovno menjavo, pozneje pa je lahko prerasla v neagrarno dejavnost, namenjeno trgu. Zemljiška gospostva so tovrstno dejavnost spodbujala, na eni strani in sprva kot odjemalci določenih obrtnih izdelkov, na drugi strani in s časom vedno intenzivneje pa preko zahtev po denarnih dajatvah, ki so podložnike silile v trgovino.

Kmetje so poleg viškov poljedelske in živinorejske proizvodnje na trg dostavljali tudi obrtne izdelke. Prve vesti o obstoju kmečke obrti najdemo v urbarjih, kjer se ponekod med dajatvami pojavljajo posamezni obrtni izdelki (Blaznik 1980, 249). Omenjajo se izdelki tekstilne obrti: vreče in vrvi (Blaznik 1963, 127; Bizjak 2006b, 186), platno, loden; lesarske obrti: palice, ${ }^{\text {15 }}$ hlodi, deske ${ }^{16}$ sodi, sklede (Pavlin 2006, 159); železarske obrti: surovo železo (Blaznik 1963, 130, 166, 180, 211) in podkve (Kos 1954, 303-5).

V doslej edini specialni študiji o podeželski obrti na Slovenskem Blaznik za ozemlje škofjeloškega gospostva ugotavlja, da so se podložniki ukvarjali pretežno z živilskimi in oblačilnimi obrtmi ter s tesarstvom in kovaštvom (Blaznik 1959, 93). Na vrste obrti na podeželju je do neke mere mogoče sklepati tudi na podlagi obrtniških priimkov, ki jih najdemo v urbarjih pri posestnikih kmetij. Priimke v urbarjih prvič bolj sistematično navajane srečujemo od sredine 15. stoletja dalje. Priimki so namreč začeli nastajati šele v tem času oz. malo prej. Eden od tipov se nanaša na de-

15 Urbar Polhov Gradec 1498, ARS, AS 1, šk. 74, fol. 40.

16 Orožen 1876, 234; Kos 1954, 265; Urbar Radovljica 1498, ARS, AS 174, šk. 246, p. 98. 
javnost oz. poklic, ki ga je dotični opravljal. Ker gre za čas nastajanja priimkov, je velika verjetnost, da le-ti še dokaj verodostojno odražajo dejansko dejavnost, ki so jo z njimi zabeleženi ljudje opravljali. Ker gre za posestnike hub, torej ljudi, ki so bili v prvi vrsti kmetje, lahko analiza obrtniških priimkov pokaže na vrste obrtnih dejavnosti na območju gospostva. Tudi tovrstna analiza kaže predvsem na živilske, oblačilne, lesarske, železarske obrti in lončarstvo. Živilske panoge zastopajo poklicni priimki, kot so Mülner, Mulnerčič (mlinar) ${ }^{17}$ in Fleischhaker (mesar), ${ }^{18}$ med oblačilnimi najdemo tkalce (Weber, (T)Kalec, Kalczicz), ${ }^{19}$ krznarje (Kursnar, Kursner), ${ }^{20}$ krojače (Schneider), ${ }^{21}$ čevljarje (Calcifex, Schuster) ${ }^{22}$ in klobučarje (Glubutzar). ${ }^{23}$ Med tistimi, ki so se ukvarjali z lesnopredelovalnimi obrtmi, se navajajo tesarji (Carpentarius, Zimmerman, Czymerman), ${ }^{24}$ mizarji (Tischler), ${ }^{25}$ Žagarji (Sager), ${ }^{26}$ izdelovalci desk oz. skodel (Prettner, Skodlar), ${ }^{27}$ strugar-

17 Blaznik 1959, 93; Orožen 1876, 227, 267, 272, 277, 287; Urbar Polhov Gradec 1498, ARS, AS 1, šk. 74, fol. 3'; Urbar Šumberk 1463, HHStA, FAA, A 15/113, fol. 21'. Urbar Polhov Gradec 1498, ARS, AS 1, šk. 74, fol. 4; Urbar Šumberk 1463, HHStA, FAA, A 15/113, fol. 10.

Blaznik 1959, 92-3; Orožen 1876, 230, 236, 239, 240, 246, 247, 252, 254, 255, 280, 294, 295; Pavlin 2006, 94, 116; Urbar Radovljica 1498, ARS, AS 174, šk. 246, p. 2, 32, 33; Urbar Polhov Gradec 1498, ARS, AS 1, šk. 74, fol. 1; Urbar Gamberk 1498, ARS, AS 1, šk. 81, p. 59; Urbar Rihemberk 1502, ARS, AS 1, šk. 105, fol. 16', 18'; Urbar Turjak 1464 HHStA, FAA, C 55/1, fol. 59, 67; Urbar Šumberk 1463, HHStA, FAA, A 15/113, fol. $3,26,34^{\prime}$.

20 Urbar Rihemberk 1502, ARS, AS 1, šk. 105, fol. 3', 38; Urbar Turjak 1464 HHStA, FAA, C 55/1, fol. 13'; Urbar Šumberk 1463, HHStA, FAA, A 15/113, fol. 67.

Blaznik 1959, 95; Orožen 1876, 222, 239, 252, 263, 265; Pavlin 2006, 126, 144, 150, 166; Urbar Radovljica 1498, ARS, AS 174, šk. 246, p. 39, 55; Urbar Polhov Gradec 1498, ARS, AS 1, šk. 74, fol. 1, 22; Urbar Gamberk 1498, ARS, AS 1, šk. 81, p. 67; Urbar Šumberk 1463, HHStA, FAA, A 15/113, fol. 3, 18, 20, 20 '.

Blaznik 1959, 95; Kos 1948, 60, 70; Kos 1954, 115, 211, 218, 219; Orožen 1876, 245, 248, 260, 270, 273, 297) Bizjak 2006, 193, 218; Pavlin 2006, 139, 152, 160, 167; Urbar Polhov Gradec 1498, ARS, AS 1, šk. 74, fol. 2, 14; Urbar Gamberk 1498, ARS, AS 1, šk. 81, p. 6o; Urbar Naklo 1498, ARS, AS 1, šk. 100, fol. 13; urbar Križe 1498, ARS, AS 1, šk. 75, fol. 5'; Urbar Kamnik 1494, ARS, AS 1074, 8ou, fol. 8; Urbar Rihemberk 1502, ARS, AS 1, šk. 105, fol. 36', 37, 37'; Urbar Turjak 1464 HHStA, FAA, C 55/1, fol. 27; Urbar Šumberk 1463, HHStA, FAA, A 15/113, fol. 2.

23 Pavlin (2006, 152; Urbar Rihemberk 1502, ARS, AS 1, šk. 105, fol. 19.

24 Blaznik (1959, 93; Bizjak 2006, 186; Orožen 1876, 224, 234, 253; Pavlin 2006, 135, 138, 153; Urbar Radovljica 1498, ARS, AS 174, šk. 246, p. 2; Urbar Turjak 1464 HHStA, FAA, C 55/1, fol. 37 .

Urbar Naklo 1498, ARS, AS 1, šk. 100, fol. 10'. Blaznik 1959, 95. 
ji (Draxel) ${ }^{28}$ kolarji (Kolar, Wagner), ${ }^{29}$ sitarji (Sitar) ${ }^{30}$ in sodarji (Sodar, Pinter). ${ }^{31}$ Od kovinskopredelovalnih panog so se kmetje ukvarjali predvsem $\mathrm{s}$ kovaštvom; $\mathrm{v}$ urbarjih pogosto naletimo na priimek Smid, Schmid,$^{32}$ tudi Faber ${ }^{33}$ redkeje pa se omenjajo kovačnice. ${ }^{34}$ Dokaj pogost je $\mathrm{v}$ urbarjih tudi priimek $\mathrm{Ha}(\mathrm{f})$ fner, ki kaže na lončarsko obrt, ${ }^{35}$ nekoliko redkeje naletimo na zidarje (Mawrer, Sydar), ${ }^{36}$ pečarje (Petschar) ${ }^{37}$ in opekarje (Farnasar).$^{38}$

Do neke mere - sicer v zelo omejenem obsegu in $\mathrm{z}$ rezervo - je na podlagi teh podatkov mogoče sklepati tudi na obseg posameznih obrti v nekem okolju. Za takšno oceno morajo biti izpolnjeni trije temeljni pogoji: a) vir (urbar) poleg osebnih imen bolj ali manj sistematično navaja tudi priimke podložnikov, b) okolje, naklonjeno načinu dodeljevanja priimkov glede na opravljanje poklica/dejavnosti, c) izvor vira iz časa nastajanja priimkov (čas okoli sredine 15. stoletja), ko se le-ti večinoma še dejansko ujemajo $s$ poklicem/z dejavnostjo njihovih nosilcev. Te tri pogoje $\mathrm{v}$ celoti izpolnjujeta le urbarja za posest plemiške rodbine Turjaških iz šestdesetih let 15. stoletja. Na podlagi teh dveh (urbarja za Turjak 1464 in Šumberk 1463) (9 $^{3}$ je mogoče izdelati vzročno študijo. Rezultate je potrebno jemati z določeno mero rezerve, saj je kljub navedenemu še vedno treba upoštevati možnost, da vsi, ki so se z neko dejavnostjo ukvarjali, niso nujno nosili ustrezajočega priim-

28 Urbar Gamberk 1498, ARS, AS 1, šk. 81, p. 67; Blaznik 1963, 307, 323.

29 Blaznik 1959, 95; Urbar Gamberk 1498, ARS, AS 1, šk. 81, p. 36; Urbar Naklo 1498, ARS, AS 1, šk. 100, fol. 13; Urbar Rihemberk 1502, ARS, AS 1, šk. 105, fol. 15.

30 Urbar Rihemberk 1502, ARS, AS 1, šk. 105, fol. 39', 41'.

31 Blaznik 1959, 96; Orožen 1876, 252; Urbar Polhov Gradec 1498, ARS, AS 1, šk. 74, fol. 1; Urbar Rihemberk 1502, ARS, AS 1, šk. 105, fol. 31', 36'; Urbar Turjak 1464 HHStA, FAA, C 55/1, fol. 68; Urbar Šumberk 1463, HHStA, FAA, A 15/113, fol. 53

32 Blaznik 1959, 95; Orožen 1876, 222; Kos 1954, 133, 139, 140; Pavlin 2006, 94, 116, 120 , 132, 160, 166; Urbar Radovljica 1498, ARS, AS 174, šk. 246, p. 34, 38, 54, 82; Urbar Polhov Gradec 1498, ARS, AS 1, šk. 74, fol. 22'; Urbar Križe 1498, ARS, AS 1, šk. 75, fol. 3; Urbar Rihemberk 1502, ARS, AS 1, šk. 105, fol. 12, 36'; Urbar Turjak 1464 HHStA, FAA, C 55/1, fol. 5', 6, 7'; Urbar Šumberk 1463, HHStA, FAA, A 15/113, fol. 19.

33 Kos 1954, 61, 64, 65, 66; Orožen 1876, 262, 291; Bizjak 2006, 193.

34 Urbar Rihemberk 1502, ARS, AS 1, šk. 105, fol. 4.

35 Blaznik 1959, 95; Kos 1954, 135, 224; Orožen 1876, 256, 258; Pavlin 20o6, 94, 116; Urbar Radovljica 1498, ARS, AS 174, šk. 246, p. 13, 16, 54; Urbar Kamnik 1494, ARS, AS 1074, 8ou, fol. 13; Urbar Rihemberk 1502, ARS, AS 1, šk. 105, fol. 8', 18'.

36 Blaznik 1959, 93; Kos 1954, 211, 219, 260; Pavlin 2006, 95, 118, 127, 167.

37 Urbar Naklo 1498, ARS, AS 1, šk. 100, fol. 6.

38 Pavlin 2006, 95.

39 Urbar za Turjak 1464, HHStA, FAA, C 55/1; Urbar za Šumberk 1463, HHStA, FAA, A $15 / 113$. 
ka. Urbarja sta razdeljena na urade, ki obsegajo po nekaj vasi, v vsakem od uradov pa se dokaj enakomerno pojavljajo priimki, ki kažejo na obstoj najrazličnejših, za življenje $\mathrm{v}$ tedanjem okolju potrebnih obrti (omenjajo se krznarji, usnjarji, tkalci, krojači, čevljarji, kovači, kolarji, tesarji, sodarji, lončarji, zidarji, mlinarji, peki in mesarji). Delež obrtniških priimkov v posameznih uradih gospostva se giblje med 5,7 ter 26,9 odstotki - povprečni odstotek za obe gospostvi je okoli 13 oz. 8 (gl. tabelo 5.1).

Tabela 5.I: Pojavljanje obrtniških priimkov v urbarjih

a) Gospostvo Turjak I 464

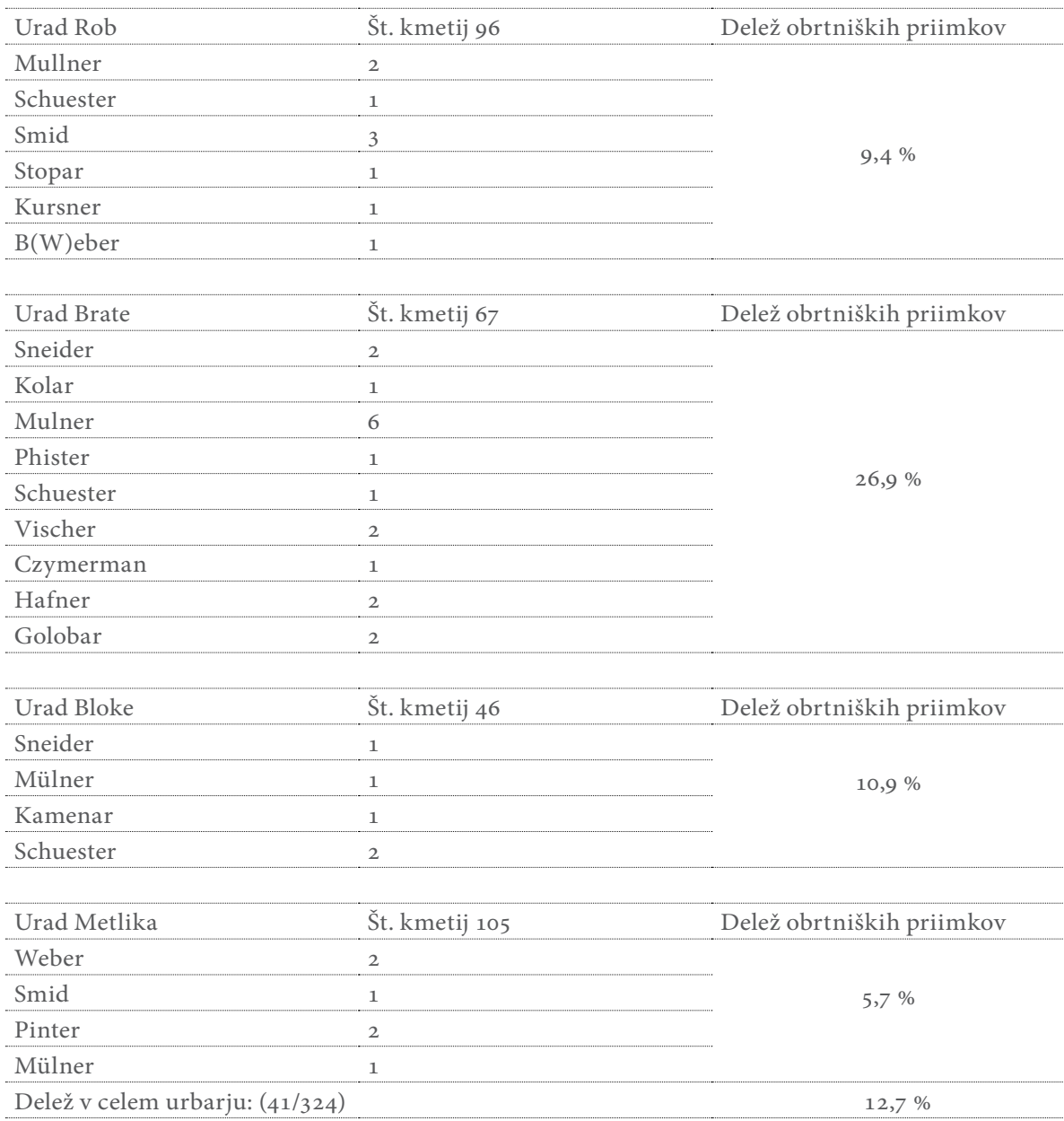


a) Gospostvo Šumberk 1463

\begin{tabular}{|c|c|c|}
\hline Urad (Šumberk) & Št. kmetij 123 & Delež obrtniških priimkov \\
\hline Schuester & 1 & \multirow{7}{*}{$8,1 \%$} \\
\hline Weber & 3 & \\
\hline Sneyder & 2 & \\
\hline Led(r)er & 1 & \\
\hline Mawrer & 1 & \\
\hline Fleischhacker & 1 & \\
\hline Kursner & 1 & \\
\hline Urad Suha Krajina & Št. kmetij 72 & Delež obrtniških priimkov \\
\hline Sneyder & 4 & \multirow{3}{*}{$9,7 \%$} \\
\hline Smid & 1 & \\
\hline Mulner & 2 & \\
\hline & & Delež obrtniških priimkov \\
\hline Urad Mokronog & Št. kmetij 94 & \multirow{4}{*}{$7,4 \%$} \\
\hline Mulner & 3 & \\
\hline Weber & 3 & \\
\hline Smid & 1 & \\
\hline \multicolumn{2}{|c|}{ Delež v celem urbarju: $(24 / 289)$} & $8,3 \%$ \\
\hline
\end{tabular}

Utečena obrtna dejavnost se je ob stalnem večanju podložniških bremen in sočasnih tendencah po vedno večjem deležu denarnih dajatev postopno preusmerjala na trg. Sprva je bil domet izdelkov domače obrti lokalno tržišče, bližnja mesta in trgi ter podeželski (letni in tedenski) sejmi ob proščenjih. Posledično so posamezni podeželski obrtniki lahko razmeroma prosperirali. Enega od dokazov za to spet najdemo v urbarjih; zaslediti je namreč ne preveč redek pojav, ko so posamezni obrtniki uživali po dve ali celo tri hube. Na Rašici na Dolenjskem je imel leta 1464 neki kovač dve hubi, poleg tega pa $\mathrm{v}$ najemu še lokalno mitnico. ${ }^{4 \circ} \mathrm{V}$ Polhovem Gradcu je imel leta 1498 neki krojač dve hubi in en domec (hofstat),$^{41}$ v bližnjem Selišču pa neki mesar dve hubi. ${ }^{42}$ Istega leta v Strahinju pri Kranju naletimo na pečarja s tremi hubami, ${ }^{43} \mathrm{v}$ Kovorju pri Tržiču pa na kovača $\mathrm{z}$ dvema. ${ }^{44}$

40 Urbar za Turjak 1464, HHStA, FAA, C 55/1, fol. 6.

41 Urbar Polhov Gradec 1498, ARS, AS 1, šk. 74, fol. 1.

42 Urbar Polhov Gradec 1498, ARS, AS 1, šk. 74, fol. 4.

43 Urbar Naklo 1498, ARS, AS 1, šk. 100, fol. 6.

44 Urbar Križe 1498, ARS, AS 1, šk. 75, fol. 3-3'. 


\section{Kmečka trgovina}

Tekom srednjega veka je diferenciacija dejavnosti med agrarnim podeželjem in tržno-obrtnimi urbanimi središči dobila trdni pravni okvir, ki pa je - na obravnavanem ozemlju - že ob koncu 14. stoletja začel popuščati pod pritiski dejanskih razmer. Že leta 1389 zasledimo prvo deželnoknežjo prepoved kmečke trgovine na Kranjskem, ki je po ugotovitvah vojvode Alberta III. škodovala tako mestom in trgom kot tudi deželnoknežjim mitnicam. ${ }^{45}$ Tovrstne prepovedi so postale stalnica v drugi polovici 15. stoletja, ko je problem postajal vedno bolj pereč. Ponavljajoče se uredbe ${ }^{46}$ nazorno razkrivajo srž problema: po ustaljenih običajih so bili kmetje dolžni proizvodne viške svojih kmetij ponuditi trgovcem (in drugim kupcem) na lokalnih tržiščih (trgih in mestih). Pri tem so bili primorani plačevati mitnino ob vstopu v mesto, lokalni trgovci pa so lahko blago nakupili po nizkih cenah in služili s preprodajo. V želji za boljšim zaslužkom so kmetje svoje pridelke raje prodajali neposredno tujim trgovcem, ki so prihajali na podeželje in zaradi izogiba mitnin in vsaj enega posrednika dosegali boljše, a še vedno konkurenčne cene. Prisotnost na lokalnih tržiščih je kmetom nudila vpogled v razmere na trgu, na drugi strani pa so preko obveznosti tovorjenja, ki so jim jo nalagali zemljiški gospodje, postajali vedno mobilnejši ter spoznavali poti in pomembnejše centre v ožji ter širši okolici. Kot logična posledica tega so se nekateri posamezniki od srede 14. stoletja dalje vedno bolj vključevali tudi v trgovino na daljše razdalje; najprej so povečali domet presežkov svoje proizvodnje, ki so jih začeli tovoriti preko deželnih meja, kar pa je v končni fazi pripeljalo do precej obsežnejšega trgovanja na daljše razdalje, saj so kmetje svoje blago zamenjevali za drugo (na primer železo, žito, sol, vino ...), tega pa prodajali doma na Kranjskem ali celo tovorili v druge dežele. Postopno so prevzemali vedno večji delež trgovanja s proizvodi podeželske obrti v smislu sistematičnega odjema pri proizvajalcih in rednega zalaganja trga, $v$ končni fazi pa tudi posegali v trgovanje $\mathrm{z}$ ostalim blagom.

V začetku devetdesetih let 15 . stoletja je permanentni konflikt, na katerega so neprestano opozarjala mesta in trgi, privedel tako daleč, da je

45 Klun 1855, št. 17. Iz listine je razbrati, da ne gre za prvo tovrstno prepoved, ampak se izstavitelj sklicuje na predhodno podobno prepoved, ki sta jo izdala skupaj z bratom Leopoldom, torej v času pred dedno delitvijo (1365-1379); glej Schwind in Dopsch 1895, št. 138.

46 Poznamo naslednje prepovedi kmečke trgovine in obrti: 1428-II-10, 1461-XII-15, 1461-XII-16, 1488-III-7, 1491-V-14; Otorepec 1958, 45, 68, 71, 72; Otorepec 1959, $19,25$. 
deželni knez posredoval za dosego sporazuma med njimi in deželnim plemstvom (zemljiška gospostva so bila namreč v veliki meri iniciator in tudi zaščitnik kmečke trgovine) glede kmečke trgovine in obrti na podeželju. Sporazum, ki ga je 23. marca 1492 objavil kranjski deželni glavar Vilijem Turjaški, ${ }^{47}$ je bil zasnovan kot celostna ureditev razmerij med mesti in podeželjem, ki je sicer ščitila pravice prvih, vendar ne več v obsegu, ki ga odsevajo starejše prepovedi, pač pa je uzakonila določene kmečke »uzurpacije«, ki jih ni bilo več smiselno niti mogoče zatirati. Sporazum je v šestih členih obsegal naslednje določbe:

1) $\mathrm{Na}$ podeželju je $\mathrm{v}$ krogu razdalje ene milje od večjih mest (Ljubljane, Kranja, Kamnika in Novega mesta) oz. v krogu pol milje od ostalih mest in trgov dovoljeval le po enega kovača, čevljarja in krojača ter eno taverno (z izjemo starih, ustaljenih, ki že plačujejo dajatve v urbar).

2) Prepovedoval je vsako obrt in trgovanje (z oljem, živino, žitom, usnjenimi izdelki, s kramarijo in z ostalim blagom) pri župnijskih cerkvah v obliki oz. času tedenskih sejmov; izjema so bila le (letna) proščenja na določenih ustaljenih lokacijah.

3) Kmetom je dovoljeval trgovanje $z$ vinom, pri čemer so lahko briško, kanalsko in dolenjsko »kislo« vino uvažali, prodajali na Kranjskem kot tudi izvažali, železo, ki so ga pri tem pridobili z menjavo, pa so lahko uvažali nazaj na Kranjsko in ga prodajali v mestih in trgih, ne pa na podeželju. V nasprotju s tem sladkih vin, kot so vipavec, rebula in italijanska vina, niso smeli izvažati, pač pa so jih lahko prodajali samo na Kranjskem.

4) Kmetom je dovoljeval trgovanje s soljo v deželi in zunaj nje, prav tako z žitom in vinom, ki so ju zamenjevali za sol (z upoštevanjem zgornjih omejitev glede vin).

5) Kmetom je dovoljeval kupovanje živine na Ogrskem in prodajanje le-te na Kranjskem, prepovedoval pa izvoz v Italijo, medtem ko jim je dovoljeval izvažanje v Italijo le na lastnih kmetijah vzgojene živine in živinorejskih izdelkov (kože, mast).

6) Kmetom je načeloma prepovedoval preprodajati t. i. trgovsko blago: olje, železo, živino, kože (z zgoraj omenjenimi izjemami). 
Vendar tudi ta sporazum ni mogel zaustaviti začetih in dobro utečenih procesov oz. vedno večjega obsega kmečke trgovine. Že v dvajsetih letih 16. stoletja so zemljiške gospode in mesta na Kranjskem razmere ponovno privedle za pogajalsko mizo, kjer je bilo sporazum iz leta 1492 potrebno revidirati v korist kmečke trgovine (Žontar 1956-57, 35 sl.). Glede na navedbe meščanov iz približno istega časa je imelo kmečko trgovanje med vsemi deželami ravno na Kranjskem največji obseg (Gestrin 1965, 42).

\subsection{Trgovina s soljo}

Trgovina s soljo je bila v slovenskem prostoru od nekdaj zelo specifična. Načini oskrbe s to esencialno življenjsko potrebščino so se na starih poselitvenih območjih razvili že $\mathrm{v}$ davnini in $\mathrm{v}$ srednjem veku niso bili podvrženi kakim korenitim spremembam. V grobem je bil slovenski prostor tradicionalno razdeljen na vplivni območji kamene soli iz alpskih rudnikov (Aussee, Hallein) in jadranske morske soli. V 14. stoletju se je med tema območjema izoblikovala solna meja, ki je potekala vzdolž Karavank, zajela Savinjsko dolino in se spustila na Savo (Vilfan 1962, 133; Gestrin 1965, 153). Zahodni in osrednji slovenski prostor se je tako oskrboval z jadransko soljo, ki pa je odjemalce kljub prepovedim dostikrat našla tudi severno in vzhodno od solne meje (Gestrin 1965, 153). Ker je mreža vodotokov na tem ozemlju za rečno plovbo proti Jadranskemu morju zelo neugodna in je bila že tako razmeroma cenena sol prepuščena dražjemu tovorništvu po kopnem - kar je posledično prinašalo visoke stroške transporta za količinsko obsežno in za trgovino malo donosno blago -, se z vznikom mest poklicni trgovci na tem področju niso mogli uveljaviti in trgovanje s soljo je ostalo tradicionalno v rokah kmečkega prebivalstva (Vilfan 1962, 134). Gornjegrajski urbar iz leta 1426 navaja seznam podložnikov, ki so bili dolžni za potrebe gospostva tovoriti sol iz Slovenskega primorja. Letno so izvedli okoli 36 obveznih tovorniških poti (»voženj«), pri tem pa je zanimivo, da so podložniki vsako tovorjenje lahko kompenzirali z enim tovorom soli, kar kaže na to, da so sol tovorili tudi v lastni režiji (Gestrin 1952-53, 505, 506; Orožen 1876, 320-2). Podobno je 75 podložnikov stiškega samostana iz Trsta letno tovorilo po en tovor soli (Kosi 1998, 72; Grebenc 1973, 112).

\subsection{Trgovina $z$ drobnico $z$ Visoke Gorenjske v Furlanijo}

$\mathrm{V}$ dokumentaciji v zvezi s sporom med podložniki radovljiškega gospostva in blejskim oskrbnikom Hartmanom Kreigom s preloma 15. in 16. stoletja so se ohranila poročila o trgovanju tamkajšnjih kmetov z živino v Italijo, 
proti Bovcu, Tolminu in Čedadu. V pritožbi, ki so jo radovljiški podložniki naslovili na cesarja, navajajo, da jim je Kraig prepovedal goniti črede živine, namenjene prodaji, v Italijo, po običajnih poteh; posluževati se morajo brezpotij, zaradi česar se veliko živali pobije in podložniki tako utrpijo precejšno škodo. Kraig je v svojem zagovoru pojasnjeval, da radovljiški podložniki svoje ogromne črede koštrunov, ki štejejo po tisoč in več živali, gonijo skozi Bohinj v času najboljše paše in s tem opustošijo pašnike podložnikov blejskega gospostva (Kaspret 1889, 77, 98-9, 121-2).

\subsection{Vozna tlaka oz. urbarialna obveznost tovorjenja kot odskočna deska za "poklicno" trgovino na dolge razdalje}

Posamezna zemljiška gospostva so nekaterim svojim podložnikom nalagala obveznost tovorjenja blaga, ki so ga za svoje potrebe uvažala iz sosednjih dežel. V Gornjem Gradu je poleg omenjenih tovornikov s soljo obstajala skupina podložnikov, ki jih je bremenilo tovorjenje olja in špecerije iz Italije. Tovorniško pot $\mathrm{z}$ enim konjem je bilo mogoče odkupiti $\mathrm{z}$ denarjem v višini ene marke in pol (Gestrin 1952-53, 505, 506; Orožen 1876, 320-2). Stiški menihi so na svoji razprostranjeni posesti tovorniške obveznosti razporedili po geografskem načelu; podložnike iz širše okolice Domžal so bremenile tovorniške poti na Štajersko (v smeri Ptuja in Radgone), kmetje na Dolenjskem (v zaledju Turjaka) pa so oskrbovali samostan z dobrinami iz primorja (Grebenc 1973, 112). Še izpovednejše podatke imamo za škofjeloško gospostvo. Freisinški škofje so se v poznem srednjem veku redno oskrbovali $\mathrm{z}$ vinom iz Slovenskega primorja, predvsem $\mathrm{z}$ rebulo, ki je predstavljala nadvse pomembno tržno blago. ${ }^{48}$ Bavarska škofija, ki je leta 1067 sicer od kralja Henrika IV. prejela posest v zaledju Kopra, ki pa je, kot kaže, ostala nerealizirana (Štih 2005, 44), v poznem srednjem veku ni posedovala zemljiških kompleksov v Sredozemlju, kjer bi lahko v lastni režiji pridelovala visokokakovostna vina. Zato pa je izkoriščala neposredno bližino svojih kranjskih gospostev in preko Škofje Loke letno uvažala občutne količine rebule, občasno tudi muškata (musskatel; Bizjak 2009, 144), iz Trsta (omenja se tudi Vipava). Pošiljko, za katero so običajno potrebovali deset konj (10 tovorov rebule je obsegalo med 23 in 30 urn vina ${ }^{49}$ ), so v Škofji Loki pretovorili in poslali naprej, navadno do Oberwölza na Zgornjem Štajerskem, kjer je uprava tamkajšnjega freisinškega gospostva poskrbela za nadaljnji transport. Vino so tovorili podložniki v okviru svojih delovnih obveznos-

48 Glej zgoraj, op. 13.

49 Prostornina tržaške urne je znašala okoli 65 litrov, Herkov 1982-85, 463-4. 
ti in celotni stroški so se gibali med 25 in 45 markami oglejskih pfenigov letno. ${ }^{50}$ Urbar iz leta 1501, denimo, konkretno navaja, da so bili podložniki iz bitenjskega urada dolžni tovoriti vino na relaciji med Škofjo Loko in Mauterndorfom (Blaznik 1963, 114, 352). Blaznik v svoji študiji predlaga možnost obstoja kombiniranih tovornih karavan, sestavljenih iz trgovcev in podložniških tovornikov. $\mathrm{V}$ tem primeru bi bilo uvajanje podložnikov v trgovanje še toliko lažje in očitnejše (Blaznik 1973, 93).

Kmečki tovorniki so $s$ časom prevzemali vedno večji delež tovorniškega prometa tudi kot najemniška delovna sila v službi poklicnih trgovcev. Mitninske knjige s konca srednjega veka kažejo, da je večina tovorniškega prometa na Kranjskem oz.s Kranjske v sosednje dežele potekala v času mrtve sezone kmečkih del (od novembra do januarja) oz. tik pred žetvijo in po njej (junija in avgusta), kar jasno kaže, da je bila ta dejavnost v veliki meri odvisna od kmečkega prebivalstva (Kosi 1998, 141).

\section{Zaključek}

Trgovanje kmetov je bilo torej ob koncu srednjega veka dodobra razvejana dejavnost $\mathrm{v}$ polnem razmahu. Ko iščemo vzroke za njen vznik, ne moremo mimo organizacije in ustroja zemljiškega gospostva, ki je ves čas delovalo kot njen spodbujevalec. Eden poglavitnih vzrokov, ki je kmete silil v trgovanje, so bile denarne dajatve.

Kdaj točno so zemljiška gospostva $\mathrm{v}$ slovenskem prostoru začela uvajati prve denarne dajatve, je težko ugotoviti. Pojav je pogojen $\mathrm{z}$ denarnim obtokom, reorganizacijo zemljiškega gospostva iz pridvornega $v$ hubni sistem ter z obstojem lokalnega trga, ki pa se zopet navezuje na obstoj urbanih naselij. Denarni obtok je v zahodni Evropi po kolapsu v 7. začel okrevati že v 10. stoletju (Spufford 1988, 12 sl.). Čeprav je v jugovzhodnem delu cesarstva zaznavna določena zamuda, pa je bližina Italije ugodno vplivala na ponovno oživitev vsaj že v prvi polovici 12. stoletja, ko se v bližnjem sosedstvu dodobra uveljavijo posamezne kovnice (Oglej, Breže), v začetku 13. stoletja pa pride do razmaha kovnic tudi na slovenskem ozemlju (Kos 1996, 158-74). Ustanavljanje zemljiških gospostev se je pri nas pomembneje začelo uveljavljati šele po končanih madžarskih vpadih, ob koncu 10. stoletja (Vilfan 1980, 111), ko je v srednji Evropi že začel prodirati - v 11. in 12. stoletju pa prevladal - hubni sistem. Že prva zemljiška gospostva pri nas so bila verjetno kombiniranega tipa, pridvorni sistem pa domnevno ni

50 Obračuni redno vsebujejo razčlenjene postavke o nakupu vina, Bizjak 2007, 86-7, 101-2; Bizjak 2008, 110, 120; Bizjak 2009, 127-8; prim. Blaznik 1968, 50-2. 
dosegel občutnejših razsežnosti (zadnji znani ostanki so dokumentirani v blejskem urbarju iz 1. 1253; Bizjak 2006b, 158, 188). Čeprav je bila notranjost slovenskega ozemlja v pretežni meri ruralna, se vendar že zgodaj pojavijo posamezni urbani oz. predurbani centri, katerih poglavitna funkcija je lokalna trgovina (Ptuj, Kranj, Slovenj Gradec, Škofja Loka, Ljubljana; Kosi 2009). Vsi ti argumenti kažejo na to, da so morala zemljiška gospostva vsaj že nekje ob koncu 11. ali v začetku 12. stoletja del dajatev pobirati v denarju. Tezo potrjuje dejstvo, da so denarne dajatve dokumentirane že v najstarejšem ohranjenem urbarju za slovensko ozemlje - freisinškem urbarju za Škofjo Loko iz l. 116o (Blaznik 1963, 127-8).

Obseg denarnih dajatev se je do konca 15. stoletja v nekaterih gospostvih postopno povečeval. Tako na primer na ozemlju freisinškega loškega gospostva: $131055 \%$, 1396-1400 65 \%, 1437-1500 75 \% (Zahn 1871, 127-8; Bizjak 2003, 182, 184), ali pa na ozemlju gornjegrajskega gospostva ljubljanske škofije: $142644 \%, 1490-150058 \%$ (Bizjak 2003, 218). Vendar pa naletimo tudi na primere $\mathrm{z}$ drugačnim trendom, na primer briksensko blejsko gospostvo: 125351 \%, 130919 \%, 146430 \% (Bizjak 2006b, 166). Čeprav je na prelomu iz 15. v 16. stoletje $\mathrm{v}$ nekaterih okoljih še prevladovala naturalna renta, je bil odstotek denarnih dajatev v večini gospostev večji od $50 \%$ (Jablje 149312 \%, Gamberk 149834 \%, Križe 149846 \%, Kamnik 149350 \%, Rihemberk 150250 \%, Gorica 150751 \%, Naklo 149859 \%, Kostel 149469 \%, Radovljica 70 \%, Kočevska Reka 76 \%, Ljubljanski stolni kapitelj 1499 81 \%, Polhov Gradec $87 \%$ ). ${ }^{\mathrm{si}}$ Na podlagi tega lahko trdimo, da so ob koncu srednjega veka kmetje vsaj polovico tistega dela svoje produkcije, ki ni bil namenjen samooskrbi, sami neposredno dostavljali na trg.

Območja $\mathrm{z}$ visokim odstotkom denarnih dajatev se $\mathrm{v}$ veliki meri pokrivajo $\mathrm{z}$ območji, ki jih historiografija prepoznava kot tista, na katerih sta se zaradi ugodne prometne lege $\mathrm{v}$ večji meri kot drugod razvila kmečko tovorništvo in kmečka trgovina. Kosi kot take navaja naslednje predele: Kras Čičarijo, Pivško, okolico Loža in Cerknice, Bloke, Velike Lašče, Dobrepolje in Suho krajino, dalje Ribnico, Ortnek in Kočevsko, na

51 Podatki so izračunani na podlagi originalnih urbarjev, ki se vsi razen enega (Ljubljanski stolni kapitelj 1499 - NŠAL, KAL, U1) nahajajo v Arhivu Republike Slovenije: Gamberk 1494 - ARS, AS 1, Vic. a., šk. 81; Križe 1498 - ARS, AS 1, Vic. a., šk. 75; Kamnik 1493 - ARS, AS 1074, Zb. Urbarjev, 8ou; Naklo 1498 - ARS, AS 1, Vic. a., šk. 100; Kostel 1494 - ARS, AS 1, Vic. a., šk. 83; Radovljica 1498 - ARS, AS 174, Terezijanski kataster za Kranjsko, šk. 246; Kočevska Reka 1498 - ARS, AS 11, Komisija za fevdne zadeve za Kranjsko, št. 23, fasc. 15; Polhov Gradec $1500-$ ARS, AS 1, Vic. a., šk. 74; Rihemberk 1502 - ARS, AS 1, Vic. a., šk. 105. Urbarja za gospostvi Jablje 1493 in Gorica 1507 sta preračunan po edicijah, Kožuh idr. 2014, 217-32; Pavlin 2006, 107-202. 
Notranjskem okolico Postojne, Planine, Logatca, širšo okolico Ljubljane in Vrhnike, na Gorenjskem pa ozemlje gospostev Smlednik, Škofja Loka in Radovljica (Kosi 1998, 143).

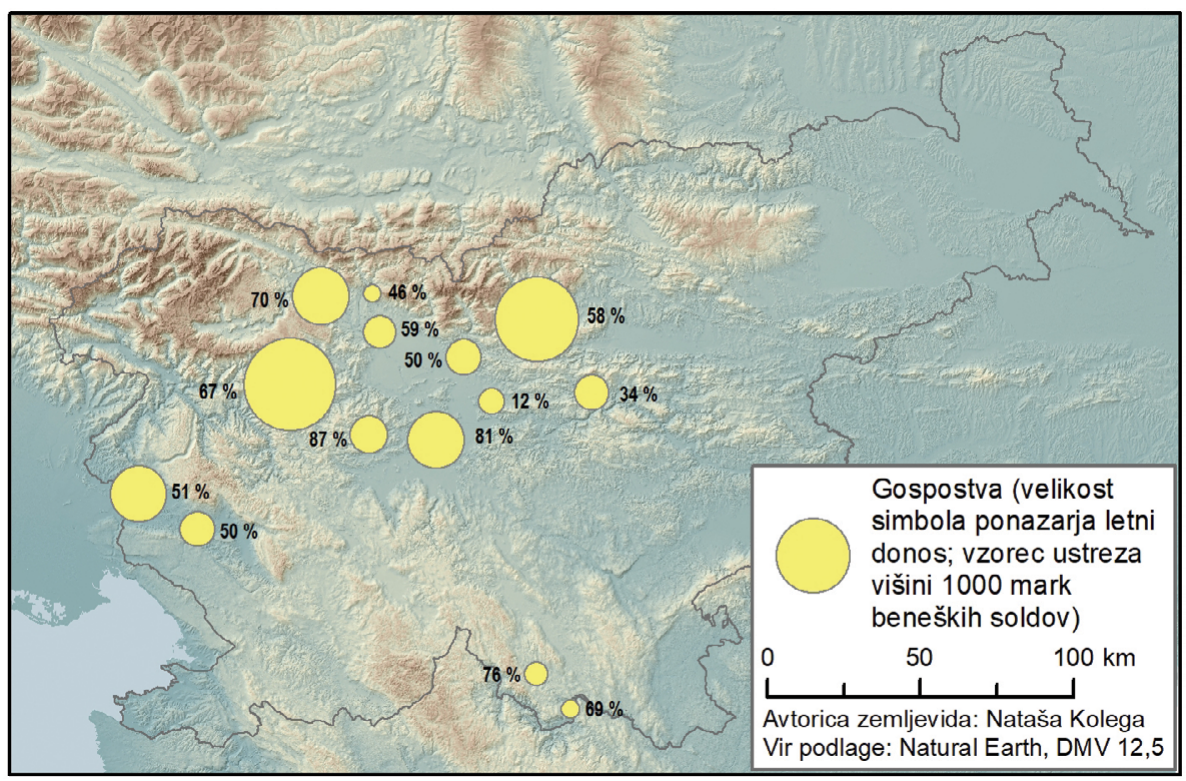

Slika 5.r: Delež denarnih prihodkov v izbranih slovenskih zemljiških gospostvih med letoma I $490-1510$

\section{Viri in Literatura}

Arhivski viri

AEM: Archiv der Erzdiözese München und Freising

Heckenstaller's Frisingensia 164, Register izdatkov Škofjeloškega gospostva 1491

ARS: Arhiv Republike Slovenije, Ljubljana

AS 1: Vicedomski urad za Kranjsko

škatla 74, Urbar gospostva Polhov Gradec 1498

škatla 75, Urbar urada Križe 1498-1501

škatla 81, Urbar gospostva Gamberk 1498

škatla 100, Reformirani urbar urada Naklo 1498

škatla 105, Urbar gospostva Rihemberk 1498 
AS 2: Deželni stanovi za Kranjsko

AS 11: Komisija za fevdne zadeve za Kranjsko, št. 23, Urbar Kočevska Reka 1498

AS 174: Terezijanski kataster za Kranjsko, škatla 246, Reformirani urbar urada Radovljica 1498

AS 1063: Zbirka listin

AS 1074: Zbirka urbarjev, 8ou, Urbar deželskega sodišča Kamnik 1494

DAK: Diözesanarchiv Klagenfurt:

HS 106: Obračuni krških gospostev v Marki 1425-1437

HS 122: Obračuni krških gospostev v Marki 1438-1452

HHStA: Haus-, Hof- und Staatsarchiv, Dunaj

FAA: Fürstlich Auersperg'sches Archiv

A 15/113, Urbar za gospostvo Šumberk 1463

C 55/1, Urbar za gospostvo Turjak 1464

NŠAL: Nadškofijski arhiv Ljubljana

KAL: Kapiteljski arhiv

Urbar 1

\section{Objavljeni viri}

Bizjak, M., ur. 2005. »Srednjeveški obračuni freisinške škofije 1. Obračuni gospostev Škofja Loka in Klevevž 1395-1401.« Loški razgledi 52: 11-28.

Bizjak, M., ur. 2006a. »Srednjeveški obračuni freisinške škofije 2. Obračuni gospostev Škofja Loka 1399-1401 in Klevevž 1395-1400.« Loški razgledi 53: 315-68.

Bizjak, M., ur. 2006b. Urbarji briksenske škofije (Die Urbare des Hochstifts Brixen): 1253-1464. Srednjeveški urbarji za Slovenijo 5. Thesaurus memoriae. Fontes 3. Ljubljana: Založba ZRC.

Bizjak, M., ur. 2007. »Srednjeveški obračuni freisinške škofije 3. Obračuni gospostva Škofja Loka 1437-1439."Loški razgledi 54: 353-80.

Bizjak, M., ur. 2008. »Srednjeveški obračuni freisinške škofije 4. Obračuni gospostva Škofja Loka 1439-1442.« Loški razgledi 55: 435-58.

Bizjak, M., ur. 2009. »Srednjeveški obračuni freisinške škofije 5. Obračuni gospostva Škofja Loka 1441-1478.« Loški razgledi 56: 435-62. 
Bizjak, M., ur. 2016. Deželnoknežji obračuni za Kranjsko (Landesfürstliche Abrechnungen für Krain) 1436-1448. Srednjeveške računske knjige za Slovenijo 1. Thesaurus memoriae. Fontes 12. Ljubljana: Založba ZRC.

Bizjak, M., in A. Žižek, ur. 2010. Knjiga obračunov celjskih mestnih sodnikov 1457-1513. Celje: Zgodovinski arhiv Celje, Založba ZRC.

Blaznik, P., ur. 1963. Urbarji freisinške škofije. Srednjeveški urbarji za Slovenijo 4. Viri za zgodovino Slovencev 4. Ljubljana: SAZU.

Erich, J., ur. 1896. Das Marienburger Tresslerbuch der Jahre 1399-1409. Königsberg i. Pr.: Verlag von Thomas \& Oppermann.

Hirsch, Th., M. Toppen in E. Strehlke, ur. $1965^{2}$. Scriptores rerum Preussicarum: Die Geschichtsquellen der preussischen Vorzeit. Bd. III. Frankfurt am Main: Minerva GMBH.

Klun, V. F., ur. 1855. Diplomatarium Carniolicum I. Laibach: Ign. v. Kleinmayr \& Fedor Bamberg.

Kos, M., ur. 1948. Urbarji Slovenskega primorja 1. Srednjeveški urbarji za Slovenijo 2. Viri za zgodovino Slovencev 2. Ljubljana: SAZU.

Kos, M., ur. 1954. Urbarji Slovenskega primorja 2. Srednjeveški urbarji za Slovenijo 3. Viri za zgodovino Slovencev 3. Ljubljana: SAZU.

Kožuh, T., N. Merljak, M. Mezek in M. Bizjak, ur. 2014. »Seminar iz temeljnih zgodovinskih ved, UNG 2012-2013: Urbar deželnoknežjega urada Jablje 1493."Arhivi 37 (1): 217-32.

Orožen, I., ur. 1876. Das Benediktiner-Stift Oberburg. Das Bistum und die Diözese Lavant II.1. Marburg: samozaložba.

Otorepec, B., ur. 1958. Listine mestnega arhiva ljubljanskega 1320-1470. Gradivo za zgodovino Ljubljane v srednjem veku III. Ljubljana: Mestni arhiv Ljubljanski.

Otorepec, B., ur. 1959. Listine mestnega arhiva ljubljanskega 1471-1521. Gradivo za zgodovino Ljubljane v srednjem veku IV. Ljubljana: Mestni arhiv Ljubljanski.

Otorepec, B., ur. 1995. Izbrano gradivo za zgodovino gozdarstva na Slovenskem $v$ srednjem veku. Viri za zgodovino gozda in gozdarstva na Slovenskem 8. Ljubljana: Gozdarska založba.

Pavlin, V., ur. 2006. Goriško gospostvo ob prehodu pod Habsburžane na osnovi urbarja iz leta 1507. Nova Gorica: Goriški muzej.

Redlich, O., ur. 1886. Die Traditionsbücher des Hochstifts Brixen vom zehenten bis in das vierzehnte Jahrhundert. Acta Tirolensia 1. Innsbruck: Verlag der Wagner'schen Universitäts-Buchhandlung. 
Schwind, E., in A. Dopsch, ur. 1895. Ausgewählte Urkunden zur VerfassungsGeschichte der deutsch-österreichischen Erblande im Mittelalter. Innsbruck: Wagner'sche Universitäts-Buchhandlung.

Wiessner, H., ur. 1951. Gurker Urbare (Bistum und Kapitel) im Auswahl aus der Zeit von 1285 bis 1502. Österreichische Urbare III. 3. Band. I. Teil. Wien: Verlag Adolf Holzhausens Nachfolger.

Zahn. J, ur. 1871. Codex diplomaticus Austriaco-Frisingensis III. Fontes rerum Austriacarum II. 36. Wien: Karl Gerold's Sohn.

\section{Literatura}

Bizjak, M. 1997. "Apnarstvo na loškem ozemlju v luči srednjeveških virov.» Loški razgledi 44 (1): 34-45.

Bizjak, M. 2003. Ratio facta est: Gospodarska struktura in poslovanje poznosrednjeveških gospostev na Slovenskem. Ljubljana: Založba ZRC.

Bizjak, M. 2012. »Grad kot središče zemljiškega gospostva.« Kronika 60 (3): 433-42.

Bizjak, M. 2013. »Srednjeveške računske knjige kot vir za okoljsko zgodovino.« Ekonomska i ekohistorija 9 (9): 81-96.

Blaznik, P. 1958. Zemljiška gospostva v območju freisinške dolenjske posesti. Ljubljana: SAZU.

Blaznik, P. 1959. »O podeželski obrti na loškem ozemlju do začetka 16. stoletja.«Loški razgledi 6 (1): 91-7.

Blaznik, P. 1968. »Stare prometne povezave med Škofjo Loko in Freisingom.« Loški razgledi 15: 49-55.

Blaznik, P. 1970. »Kolektivna kmečka posest.« V Gospodarska in družbena zgodovina Slovencev. Zgodovina agrarnih panog, zv. 1, uredili P. Blaznik idr., 149-6o. Ljubljana: Slovenska akademija znanosti in umetnosti in Državna založba Slovenije.

Blaznik, P. 1973. Škofja Loka in loško gospostvo (973-1803). Škofja Loka: Muzejsko društvo Škofja Loka.

Blaznik, P. 1980. "Podložniške obveznosti do zemljiškega gospostva.« V Gospodarska in družbena zgodovina Slovencev. Zgodovina agrarnih panog, zv. 2, uredili P. Blaznik idr., 241-78. Ljubljana: Slovenska akademija znanosti in umetnosti in Državna založba Slovenije.

Dasler, C. 2001. Forst und Wildbann im frühen deutschen Reich. Die königlichen Privilegien für die Reichskirche vom 9. bis zum 12. Jahrhundert. Köln, Weimar, Wien: Böhlau. 
Dopsch, H. 1999. Die Länder und das Reich: Der Ostalpenraum im Hochmittelalter. Österreichische Geschichte 1122-1278. Wien: Ueberreuter.

Gestrin, F. 1952-53. »Gospodarska in socialna struktura gornjegrajske posesti po urbarju leta 1426. Zgodovinski časopis 6-7: 473-514.

Gestrin, F. 1965. Trgovina slovenskega zaledja s primorskimi mesti od 13. do konca 16. stoletja. Ljubljana: SAZU.

Gestrin, F. 1978. „Prispevek k kvantifikaciji kmečke trgovine v poznem srednjem veku in v 16. stoletju.«Jugoslovenski istorijski časopis 6-7: 169-78.

Grebenc, J. M. 1973. Gospodarska ustanovitev Stične ali njena dotacija 1135. Samostan Stična: Cistercijanski samostan v Stični.

Herkov, Z. 1982-85. "Dodatak uz stare mjere hrvatskog primorja i Istre.» Jadranski zbornik 12: 459-521.

Kaspret, A. 1889. „Ueber die Lage der oberkrainerischen Bauernschaft im Ausgange des XV. und im Anfange des XVI. Jahrh." Mittheilungen des Musealvereines für Krain 2: 69-148.

Kos, M. 1970. »Kolonizacija in populacija v srednjem veku.«V Gospodarska in družbena zgodovina Slovencev. Zgodovina agrarnih panog, zv. 1, uredili P. Blaznik idr., 67-88. Ljubljana: Slovenska akademija znanosti in umetnosti in Državna založba Slovenije.

Kos, P. 1996. „Der Friesacher Pfennig und seine Nachprägungen in slowenischen Gebiet."V Die Friesacher Münze im Alpen-Adria-Raum: Akten der Friesacher Sommerakademie, Friesach (Kärnten), 14. bis 18. September 1992. Grazer Grundwissenschaftliche Forschungen 2. Schriftenreihe der Akademie Friesach 1, uredil R. Härtel, 157-90. Graz: Akademische Drucku. Verlagsanstalt.

Kosi, M. 1998. Potujoči srednji vek: Cesta, popotnik in promet na Slovenskem med antiko in 16. stoletjem. Ljubljana: Založba ZRC.

Kosi, M. 2009. Zgodnja zgodovina srednjeveških mest na Slovenskem: Primerjalna študija o neagrarnih naselbinskih središčih od zgodnjega srednjega veka do 13. stoletja. Ljubljana: Založba ZRC.

Novak, V. 1970. "Živinoreja.«V Gospodarska in družbena zgodovina Slovencev. Zgodovina agrarnih panog, zv. 1, uredili P. Blaznik idr., 343-94. Ljubljana: Slovenska akademija znanosti in umetnosti in Državna založba Slovenije.

Paravicini, W. 1989. Die Preussenreisen des europäischen Adels 1. Beihefte der Francia 17/1. Sigmaringen: Thorbecke.

Paravicini, W. 1995. Die Preussenreisen des europäischen Adels 2. Beihefte der Francia 17/2. Sigmaringen: Thorbecke. 
Spufford, P. 1988. Money and Its Use in Medieval Europe. Cambridge: Cambridge University Press.

Štih, P. 2005. »Izvor in začetki škofijske posesti na današnjem slovenskem ozemlju.« V Blaznikov zbornik (= Loški razgledi. Doneski 11), uredil M. Bizjak, 35-48. Ljubljana-Škofja Loka: Založba ZRC, Muzejsko društvo Škofja Loka.

Štih, P. 2006. „Der bayerische Adel und die Anfänge von Laibach/Ljubljana.» Zeitschrift für bayerische Landesgeschichte 69 (1): 1-52.

Vilfan, S. 1962. »K zgodovini kmečkega kupčevanja s soljo.« Kronika 10 (3): 129-44.

Vilfan, S. 1980. "Zemljiška gospostva.«V Gospodarska in družbena zgodovina Slovencev. Zgodovina agrarnih panog, zv. 2, uredili P. Blaznik idr., 75-239. Ljubljana: Slovenska akademija znanosti in umetnosti in Državna založba Slovenije.

Zwitter, Ž. 2013. "Krčenje in agrarna raba gozdov na Gorenjskem v času višinske kolonizacije.« Gorenjska v obdobju glokalizacije, uredili B. Rogelj, I. Potočnik Slavič in I. Mrak, 85-98. Ljubljana: Znanstvena založba Filozofske fakultete.

Žontar, J. 1939. Zgodovina mesta Kranja. Kranj: Muzejsko društvo za Slovenijo.

Žontar, J. 1956-57. »Nastanek, gospodarska in družbena problematika policijskih redov prve polovice 16. stoletja za dolnjeavstrijske dežele s posebnim ozirom na slovenske pokrajine.« Zgodovinski časopis 10-11: 32-121. 